\title{
The Role of Technology for Language Teaching and Learning: An Evaluative Study
}

\author{
Dr Vadlamani Padma \\ Assistant Professor of English \\ Anurag University \\ Hyderabad, India \\ vadlamanipadma4@gmail.com
}

\begin{abstract}
The primary objective of this paper is to examine the role of technology for language teaching. It focusses to make English language teachers cognizant of the techniques to implement appropriately. Technology plays an essential role in teaching of English. It helps in giving a practical method to a resource. Technology when perfectly incorporated enriches the objectives of learning. Efficacious integration of technology is fruitful when students can select them to acquire information in a judicious manner, examine and combine the information, and present it professionally There is a significant development in the teaching of English language methodology with the application of new technology. Technology is unceasingly, and precipitously, growing. To maximise progressive language learning outcomes, student-teacher platforms are created extensively. Accordingly, the present English language teachers now actively integrate different technological aids devised to help the best possible teaching approaches.
\end{abstract}

Keywords: Technology, Efficacious, Precipitously, Integrate.

Technology has earned a prominent place in teaching space in contemporary times. It is widely used to bring teachers work collaboratively to create a better learning experience. 
Technology facilitates in assisting and enriching language learning. It empowers educators to familiarize classroom activities, therefore improving the language learning to make progress. Technological advances have enormously changed our lives. Innovative technologies are continuing to make strides each day.

Now, communication is not only an instinctive action yet, an indispensable attribute for endurance in cutthroat world. It is a proficiency that is required to achieve desired visions and planned goals. To learn the skills set needed for communication, technology aided education through modern practices could be used by ELT educators. Teachers should work together to connect their concepts and resources electronically. They can communicate with their fellow teachers across the world instantaneously, meet the shortcomings of their work, hone it, and provide their students with the best. This methodology enhances the process of teaching. Graddol states that "technology lies at the heart of the globalization process, affecting education work and culture. The use of English language has increased rapidly after 1960. Presently, the role and status of English is that it is the language of social context, political, sociocultural, business, education, industries, media, library, communication across borders, and key subject in curriculum and language of imparting education".

The momentousness of technology in teaching is irrefutably the capacity to link up with students adeptly. Technology is atop us and remains to evolve in its innumerable uses. While many people like to count on conventional practices of teaching, the opportunities that technology has brought into the classroom are infinite. The effect that technology has on today's students has been quite noteworthy and has absolutely changed the teaching and learning scenario. Access to education has substantially widened thereby resulting in the wide range of learning styles. Skilled learning gives teachers the chance to change for the better and to plan for these modern technology classrooms and reflects active learning methods that immensely help students. Therefore, it is important to note the significance of technology in 
education. To utilize technology tools, teachers should self-introspect students need of technology in the classroom and the skills they develop to help them in their future professions.

Communication is an indispensable attribute for survival in competitive places. It is an aptitude that is requisite to be fruitful in life. Technology needs to be incorporated into teaching practices to facilitate the learners acquire second language effectively and efficiently. Technology must be integrated into instructional practices to facilitate the learners acquire second language effectively and develop their digital literacy skills. Students of today are considered digital natives . They utilize technology efficiently and effortlessly. They ought to resolve problems, obtain data fairly and work together with the global world .Technology is advancing exponentially. It is prevalent and stupendous. It is user friendly, inexpensive, and accessible far and wide. It is easy to deal with and challenging to stop. Consequently, technological advancement is essential to understand a new language. Proper utilisation of technology, internet, and certain computer games promote language learning in a positive way . Internet transformed the whole lot. Most of the users are remote speakers. Consequently, English language has become the language of technology, which fills into the systems of our organizations.

According to Becker (2000), computers are regarded as an important instructional instrument in language classes in which teachers have convenient access, are sufficiently prepared, and have some freedom in the curriculum. Computer technology is highly considered by a lot of teachers to be a significant part of providing a high-quality education. Warschauer and Healey state that: "It is the rise of computer-mediated communication and the Internet, more than anything else, which has reshaped the uses of computers for language learning at the end of the 20th century. With the advent of the Internet, the computer-both in society and in the classroom-has been transformed from a tool for information processing and display to a tool for information processing and communication. The initial, learners of a language can now 
communicate inexpensively and quickly with other learners of speakers of the target language all over the world". Several educational institutions have initiated availing new tools in teaching theory and language laboratories, in core curriculum and syllabuses, in instructions and practices. There is a pedagogical and paradigmatic shift in teaching and learning in virtual platforms. A presentation is designed to be carried out with the help of audio-video (AV) aids. The installation of multi-media laboratories, interactive whiteboards, and smart classrooms. The language laboratories are equipped with printers, projectors, and internet connections networking all the computer systems through local area network connection.

Larsen-Freeman and Anderson (2011) claim that "technology provides teaching resources and brings learning experience to the children's world. Technology also provides lots of authentic materials and young learners may be motivated easily in a long language learning atmosphere. They also mention that electronic chatting, games, e pan pals and podcasts can be interesting for language learners. Children are generally visual learners. They want to see while they are learning. Internet and computer-based activities bring visual materials to the children's world. Children can improve their listening, reading and writing skills by means of media and internet. It is definitely a matter of concern, as there is a certain amount of alarm about digital tools of misrepresenting or distracting the learners from acquiring the language or replacing the teacher in the classroom. Technology can offer learners with diverse learning practices and styles, thus, creating a favourable environment with meaningful contexts."

Technological progress has made several innovative ways to assist the learning process and the English language laboratory is an audio-visual creation used in modern language teaching to teach LSRW skills .It initiates as a plan for exercising and creating language skills through collaborative sessions in the communicative form of teaching. The language laboratory offers broadcasting, web assisted materials and language acquisition software. 
Computer Assisted Language Learning (CALL) proposes an ideal learning environment for those who cannot gain much from the lecture method. It plays a decisive role in language learning and teaching as it makes use of immense wealth of teaching and learning materials that are offered free of cost through computer and information technologies. The programmes used in CALL are interactive, with a provision for instructor intervention whenever called for. It entails infrastructural facilities like large television, a public address system, microphones, and earphones, and internet connections. The Interactive Communications Skills Lab (ICS lab) is an extremely useful tool in infusing soft skills for interpersonal communication among the learners. It helps in the manner with their learnercentred, tools like computer, microphones, and video cameras. A scrupulously planned CALL exercise may perhaps produce a motivating atmosphere for the students to develop their language attainment and language competency.

Teachers are irreplaceable if they make good use of technologies in his/her teaching methodology. The apprehensive perceptions could be swept away, since a competent teacher knows the right manner to take advantage of the ICT tools to escalate the interest in the learners and oversee the use of technologies prudently.

The implementation and adoption of new technology indicate a significant momentum in present-day English language teaching methods .According to Jacqui Murray, "technology allows students to prove independence. It distinguishes the needs of students. Strengthens learning by using resources that students are interested in. It gives students an equal voice and empowers them to build strong content knowledge wherever they find it."

Conclusion:

These days technology is not any more a privilege for the section of students, but it is available to all the students, as it has become noticeably cheaper. Technology is global and, 
therefore, plenty of the world's information can be easily obtained through a variety of devices. The expounding use of mobile devices like mobile phones, iPods, laptops, Tablet, and wireless technologies empower the user to gain access to any type of training and instructional material from anyplace and at any time.

We are residing in an age with unparalleled prospects to share ideas with distinct people in authentic and compelling ,linguistically and culturally contextualized areas. Moreover, language teachers today are confronted with many interesting options for using technology to develop language learning exceptionally.

In short, true efforts to revise conventional techniques of instructing English, continuing outdated practices should be phased out and replaced using computer, smart devices, display, audio-visual materials, and electronic advances. Irrefutably, the aim of both conventional and contemporary technologies is to improve students' English skills and give an expanse where learning can be best facilitated. 


\section{References:}

Becker, H. J. (2000). Findings from the teaching, learning, and computing survey: Is Larry Cuban, right? Education Policy Analysis Archives, 8(51).

Graddol, D.( 1997). The Future of English. London. London: The British Council.

Jacqui, M. (2015). 13 Reasons for Using Technology in the Classroom.

Larsen-Freeman, D. Anderson, M .(2011).Techniques and principles in language teaching. Oxford: OUP.

Warschauer, M. \& Deborah Healey. (1998). Computers and language learning: an overview. Language Teaching.31(2), 57-71. 